\title{
КАЙНОЗОЙСКИЕ АЛМАЗОНОСНЫЕ ДЕПРЕССИИ ЮЖНОЙ ЧАСТИ ПОЛЮДОВА КРЯЖА (ВИШЕРСКИЙ АЛМАЗОНОСНЫЙ РАЙОН)
}

\author{
И. И. Никулин
}

\author{
ООО «Норильскгеология», г. Санкт-Петербург
}

Поступила в редакцию 4 марта 2019 г.

\begin{abstract}
Аннотация: в Западно-Уральской зоне складчатости в пределах южной части Полюдова Кряжа выделены кайнозойские алмазоносные отложения, выполняющие Волынско-Колчимскую, ИльяВожскую, Западную и Буркочимскую палеодепрессии. Они развиты преимущественно по контакту нижнесилурийских карбонатных пород и терригенных пород венд-кембрия, сформировав в плане вытянутые отрицательные формы длинной до 7,6 км, а в поперечном сечении корытообразный профиль размером до 1,1 км с элементами V-образных врезов, которые в поперечнике достигают 0,13 км. Отложения депрессий имеют полифациальный генезис, разделяясь обычно на пять (до девяти) алмазоносных (a $Q_{I I}, l d Q_{I I}, d-p Q_{I I}, d-p N$, eMZ-P) и верхний неалмазоносный (d $\left.Q_{I V}\right)$ слои. По морфологии и литологическим характеристикам изученные депрессии отнесены к коррозионно-эрозионному типу кайнозойского времени. Минеральный состав преимущественно гётит-иллитовый. Тяжёлая фракиия отложений депрессий между минералы линз и прослоев по трещинам представлена смектитами и галлуазитом. Состав тяжёлой фракции неогеновых слоёв аналогичен таковому такатинских и колчимских песчаников. В ней резко преобладает циркон (до 90\%), в меньшей степени турмалин (до 20\%), лейкоксен (до 20\%), рутил (до 9\%). Значительная доля принадлежит аутигенным минералам - лимониту, гематиту, пириту. В россыпеобразовании этих депрессий предполагается большая роль предтакатинских и мезокайнозойских химических кор выветривания, и по существу они являются промежуточными образованиями между корами выветривания и продуктами их переотложения в русловой аллювий, который разрабатывался драгами до недавнего времени.
\end{abstract}

Ключевые слова: алмаз, палеодепрессия, Кайнозой, Полюдов кряж, Вишера.

\section{CENOZOIC DIAMONDIFEROUS DEPRESSIONS OF THE SOUTHERN PART OF POLYUDOV RIDGE (VISHERA DIAMOND AREA)}

\begin{abstract}
West-Ural zone of folding within the southern part of the Polyudov Ridge, Cenozoic diamondiferous deposits are identified that carry out the Volyn-Kolchim, Ilya-Vozhsk, Western and Burkochim paleo-depressions. They are developed mainly from the contact of the Lower Silurian carbonate rocks and terrigenous Vendian-Cambrian rocks, forming elongated negative forms in terms of up to 7.6 $\mathrm{km}$ long, and in cross section a trough-shaped profile up to $1.1 \mathrm{~km}$ in size with elements of V-shaped incisions across reach 0,13 km. Depression's deposits have polyfacial genesis, usually divided into five (up to nine) diamondiferous $\left(a Q_{I I}, l d Q_{I I}, d-p Q_{I I}, d-p N\right.$, eMZ-P) and upper non-diamond-bearing $\left(d Q_{I V}\right)$ layers. According to morphology and lithological characteristics, the studied depressions are attributed to the corrosion-erosion type of the Cenozoic time. The mineral composition is predominantly goethite-illite. The heavy fraction of sedimentary depressions is similar and corresponds to the leucoxene-tourmalinezircon association. Fine minerals of the lenses and interlayers along cracks are represented by smectites and halloysite. The composition of the heavy fraction of the Neogene layers is similar to that of the Takatin- -time and Kolchim-time sandstones. It is dominated by zircon (up to 90\%), to a lesser extent tourmaline (up to 20\%), leucoxene (up to 20\%), rutile (up to 9\%). A significant proportion belongs to authigenic minerals - limonite, hematite, pyrite. The placer formation of these depressions assumes a large role of the Pre-Latino and Meso-Cenozoic chemical weathering crusts, and they are essentially intermediate formations between the weathering crust and the products of their redeposition in the channel alluvium, which was developed by dredging until recently.
\end{abstract}

Key words: diamond, paleodepression, Cenozoic, Polyudov Ridge, Vishera. 


\section{Введение}

Современное понимание геологического строения района базируется на выводах работ Н. Г. Чочиа [1], полученных в 1949-1951 гг. при проведении тематических и геолого-съёмочных работ, а также на последующих геологических съёмках, направленных на уточнение геологического и геоморфологического строения района.

Вишерский алмазоносный район по тектоническому районированию Урала расположен в ЗападноУральской зоне складчатости в пределах КожимоВишерской структуры и составляющего её Полюдовско-Колчимского антиклинория (Полюдова Кряжа) размером 120х20 км (рис. 1). Он состоит из крупных Полюдовской, Колчимской и Тулым-Парминской антиклиналей, в ядрах которых выходят отложения верхнего протерозоя и нижнего палеозоя. Югозападное крыло антиклинория почти на всем протяжении срезано Красновишерско-Ныробским (Главным) надвигом, горизонтальная амплитуда перемещения по которому 2,7-5,5 км. Колчимская и ТулымПарминская антиклинали, слагающие ядро антиклинория, представлены моноклиналями с восточным падением пород рифейско-вендского комплекса, осложненными разрывами и более поздней изоклинальной складчатостью с разнонаправленными надвигами.

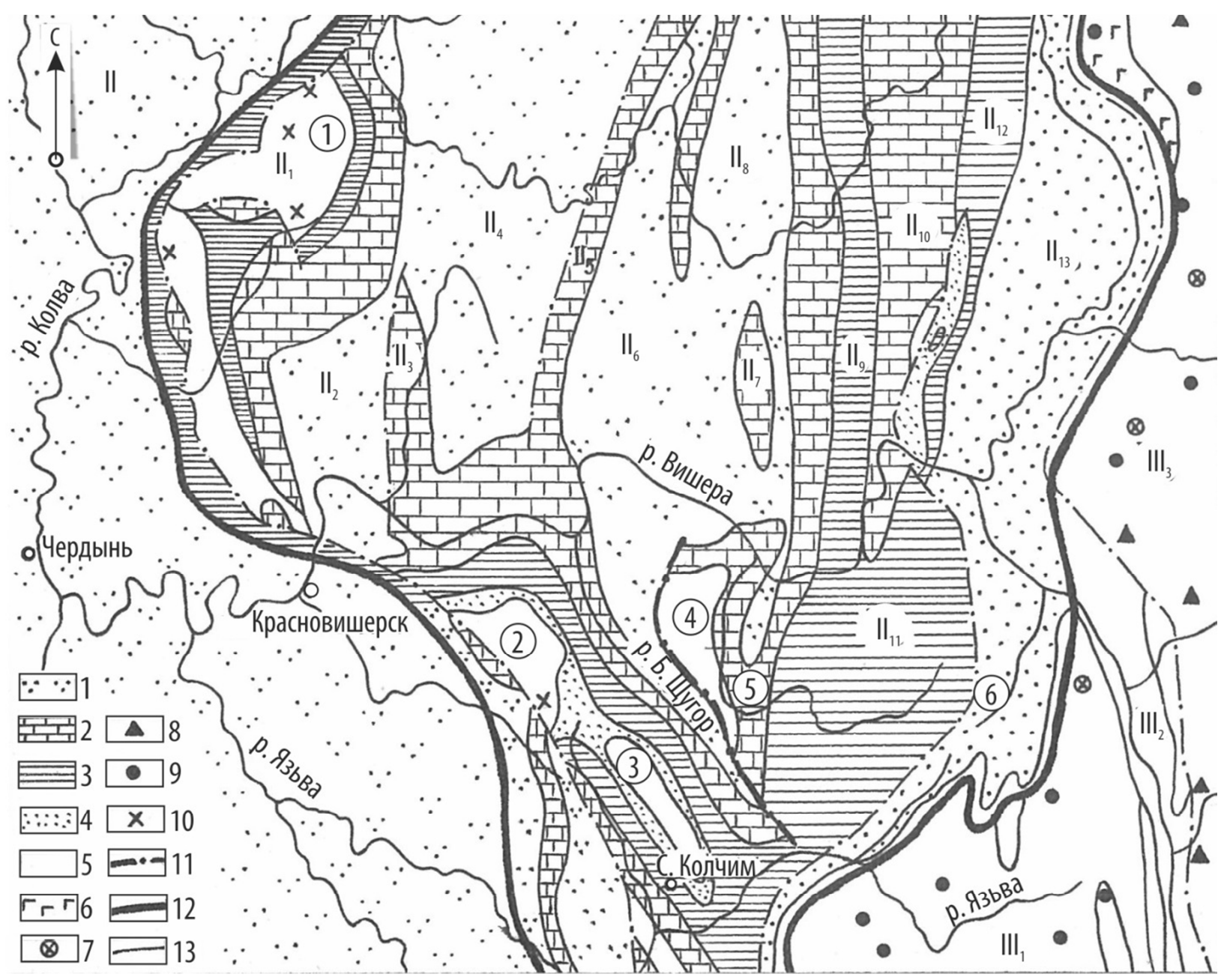

Pис. 1. Тектоническая схема Полюдовско-Колчимского антиклинория Западного склона Урала (на основе В.В. Попова, 1968; П.А. Софроницкого, 1969; И.Д. Соболева, 1983; Ф.А. Курбацкой, 1991): 1-4 структурные ярусы верхнего структурного этажа и формации: 1 - пермский (молассовая формация); 2 - визейско-верхнекаменноугольный (карбонатная и угленосная); 3 эйфельско-турнейский (карбонатная, карбонатно-терригенная, терригенная и граувакковая); 4 - ордовикско-нижнедевонский (граувакковая, карбонатная и карбонатно-терригенная); 5 - нижний структурный этаж (спагмитовая ашинского; аркозовая, сланцевая и карбостромовая каратауского структурного яруса); 6-10: 6 - эффузивно-диабазовая; 7 - гранитовая; 8 - ультрабазитовая; 9 габбро-диабазовая; 10 - щелочных диабазов; 11 - разрывные нарушения; 12 - границы структур первого порядка; 13 - границы структурных ярусов. Структуры: $I$ - Предуральский краевой прогиб; $I I$ - Западно-Уральская зона складчатости: $I I_{I}-$ Полюдов кряж; $I I_{2}$ - Талицко-Булдырьинская синклиналь; $I I_{3}$ - Говорухинско-Недымская антиклиналь; $I I_{4}$ - Бужуйская синклиналь; $I I_{5}-$ Велгурско-Бердышская антиклиналь; $I I_{6}$ - Сыпучинско-Потаскуевская синклиналь; $I I_{7}$ - Пырамская антиклиналь; $I I_{8}-$ БУрундукская синклиналь; $I I_{9}$ - Сосновецко-Ямжачная антиклинальная зона; $I I_{10}$ - Золотихинско-Вайская синклиналь; $I I_{11}$ - хребет Золотой Камень; $I I_{12}$ - хребет Берёзовый Камень; $I I_{13}$ - Вишерская синклинальная зона; $I I I$ - Центрально-Уральское поднятие: $I I I_{1}-$ Кваркушско-Каменногорский антиклинорий; $I I I_{2}$ - Улсовско-Койвинский синклинорий; $I I I_{3}$ - Ляпинско-Исовский антиклинорий. В кружках: 1 - Полюдовская антиклиналь $\left(\mathrm{II}_{1}\right) ; 2$ - Колчимская антиклиналь $\left(\mathrm{II}_{1}\right) ; 3$ - Тулым-Парминская антиклиналь $\left(\mathrm{II}_{1}\right) ; 4$ - Акчимская антиклиналь $\left(\mathrm{II}_{6}\right) ; 5$ - Акчимская синклинальная зона $\left(\mathrm{II}_{6}\right) ; 6$ - моноклиналь р. Пели $\left(\mathrm{II}_{13}\right)$. 
Геологические съёмки в комплексе с геодезическими работами выполнялись под руководством А. Д. Ишкова в 1959-1965 гг., С. В. Младших, Л. В. Григорьева в 1972-1973 гг., В. К. Серебренникова в 1977-1983 гг. В результате этих работ на территорию района составлена кондиционная геологическая карта масштаба 1:50000. Рыхлые отложения района работ изучены (мощность, литология) буровыми скважинами и разведочными шахтами. Начало крупных геоморфологических обобщений по Северному Уралу связано с работами И. П. Краснова (1948 г.), который на основе геоморфологических предпосылок впервые высказал мысль о возможности существования на Северном Урале промышленных россыпей алмазов.

Системные изучения алмазоносных россыпей различными коллективами позволили их расчленить по фациальным признакам. В результате выделились мезозойские элювиальные образования, выравнивающие плотиковую часть. В дальнейшем в результате решения вопроса об их распространении в пределах Вишерского алмазоносного района использовались преимущественно геофизические методы, выделившие карстовые формы [2], которые размыты системой речных долин, образующих все известные россыпи алмазов (рис. 2). Уже тогда сделан вывод, что эти карстовые формы являются промежуточными коллекторами алмазов, законсервировавшими размытые отложения и способствующие их сохранению [3]. Отмечается алмазоносность на всем протяжении субмеридиональных рек, вложенных в эти депрессии. Реки субширотного направления, пересекающие депрессии, алмазоносны только в их пределах.

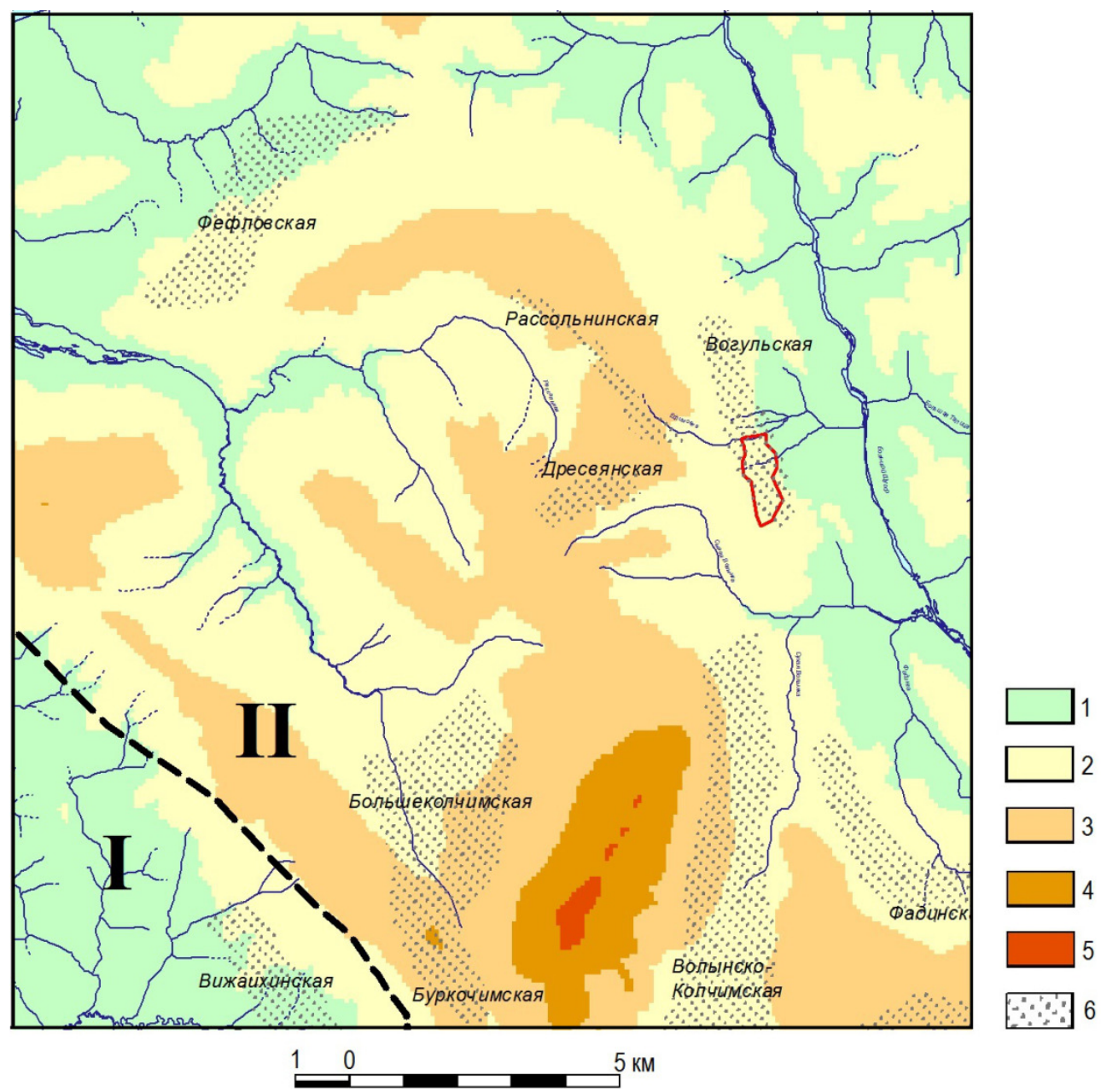

Puc. 2. Палеогеоморфологическая схема западной части Вишерского алмазоносного района: $I$ - денудационная равнина Тиманид, II - аккумулятивная-денудационная равнина Предуралья; Геоморфологические поверхности: 1 - плейстоценголоценовых аллювиальных долин и равнины Предуралья, 2 - плейстоценовая, 3 - палеогеновая, 4 - позднемезозойская, 5 - раннемезозойская, 6 - кайнозойские депрессии. Составлена В. М. Марусиным, 1990.

\section{Геология района}

В геологическом строении Вишерского алмазоносного района участвуют докайнозойские породы, формирующие два структурно-тектонических этажа, и перекрывающие их плащом рыхлые кайнозойские отложения. Нижний докембрийско-нижнепалеозойский этаж слагают образования рифея-венда (рассольнинская, деминская и низьвенская свиты) и верхнего ордовика (полюдовская свита $\left(\mathrm{O}_{3} \mathrm{pl}\right)$ ). Все они представлены метаморфическими породами: кварци- 
топесчаниками, алевроаргиллитами, мраморизированными известняками, доломитами с тиллитовидными конгломератами и конгломератами ордовика. Верхний палеозойский этаж слагают терригеннокарбонатные отложения нижнего силура-карбона. Терригенные породы приурочены к основаниям седиментационных циклов и занимают в разрезе низы стратиграфических подразделений. Это терригеннобазальная пачка колчимской свиты $\left(\mathrm{S}_{1} \mathrm{kl}\right)$ (нижний силур $\left.\left(\mathrm{S}_{1} \ln \right)\right)$, гравелито-конгломераты тактинской свиты ( $\left.\mathrm{D}_{1} \mathrm{tk}\right)$ (нижний девон $\left.\left(\mathrm{D}_{1} \mathrm{em}\right)\right)$, терригенная толща турне $\left(\mathrm{C}_{1} \mathrm{tn}\right)$. По контактам терригенных толщ с массивными и плотными карбонатами образованы субмиллониты в виде слоев дезинтегрированных глин, гравелитов и конгломератов.

На основании проведенного структурного бурения на Колчимской антиклинали Щербаковым, Щербаковой, Катаевым и др. (2002 г.) подтверждена надвиговая система границы между этажами, по которой Полюдово-Колчимский антиклинорий является безкорневой структурой (аллохтонным клиппом), надвинутой на горизонтально залегающие платформенные породы палеозоя. Восточное крыло Колчимской антиклинали слагают образования палеозоя от силура до карбона преимущественно карбонатного состава. В карбонатном разрезе имеются кластические терригенные толщи: базальная пачка гравелитов и мелкогалечных конгломератов в подошве $\mathrm{S}_{1} \mathrm{kl}$, песчаники, гравелиты и конгломераты $\mathrm{D}_{1} \mathrm{tk}$, а также алевро-аргиллиты, песчаники пашийской ( $\left.\mathrm{D}_{2} \mathrm{ps}\right)$ и кыновской $\left(\mathrm{D}_{2} \mathrm{kn}\right)$ свит, и турне карбона. Кластические толщи силура и девона являются установленными промежуточными коллекторами алмазов. Пространственно с их развитием совпадают известные месторождения россыпей алмазов в палеодепрессиях плейстоценового аллювия.

Выделяются пликативные и дизъюнктивные тектонические дислокации, но детально этот вопрос не изучался. К древним разломам относятся: 1) глубинные разломы фундамента между Русской и Печорской плитами, с которыми совпадает основной Полюдовско-Вишерский надвиг, разделяющий Предуральский краевой прогиб и Западно-Уральскую зону складчатости, 2) неустановленный глубинный разлом фундамента, по которому развита Колчимская седловинная синклиналь и 3) некоторые тектонические нарушения докембрийских пород.

В пределах Полюдовско-Колчимского антиклинория установлены 5 поверхностей выравнивания [4]: 1) раннемезозойская по гипсометрическому уровню выше 700 м, это вершина г. Помяненный Камень; 2) позднемезозойская, по отметкам от 500 до 700 м, соответствующая поверхности выравнивания основных водоразделов; 3) палеогеновая (олигоценовая) по отметкам от 350 до 500 м, отвечающая выположенному и слабонаклонному склону современных водоразделов; 5) плейстоценовая, по отметкам от 240 до 350 м современные склоны рельефа. С отметками менее 240 м связаны плейстоцен-голоценовые речные долины.
Система депрессий развита по палеогеновой и плейстоценовой геоморфологическим поверхностям.

Горизонтальные смещения, относящиеся к альпийскому тектогенезу не известны. С началом неотектонической эпохи, вследствие общего понижения базиса эрозии и физического выветривания, сформировались увалы и понижения за счёт контрастности свойств пород, выходящих на палеоповерхность. Увалы образовались преимущественно по кварцевым песчано-конгломератовым породам такатинской и полюдовской свит, а в южной части Полюдовского-Колчимского антиклинория между ними во впадинах карбонатных пород сформировались эрозионно-карстовые депрессии (рис. 3): Волынско-Колчимская, Илья-Вожская, Западная и Буркочимская [5, 6]. Они являются крупными отрицательными формами в дочетвертичном рельефе, заполненными отложениями мезозой-кайнозоя. Отложения близкие к ним по литологии и геологогеоморфологической позиции выявлены в бассейнах p. Колвы и Яйвы (Чикман-Нярская депрессия) [7].

Алмазоносность нижне- и среднепалеозойских терригенных толщ обусловлена размывом кимберлитов догерцинского возраста. Состав кластических толщ ордовика, силура и девона наследуется эрозионно-структурными кайнозойскими депрессиями, сопряженными с этими толщами пространственно [9].

В пределах района Ветчаниновым В. А. (1976 г.), Серебренниковым В. К. (1983 г.) и др. выявлены три основных типа депрессий (и т.д.): эрозионно-структурные, эрозионно-карстовые, эрозионно-тектонические. Погребенные ложа депрессий, представленные карбонатными и отчасти терригенными породами палеозоя, как правило, неровные и осложнены палеокуэстами и древним карстом с развитием площадных и линейных кор выветривания по палеоповерхностям и трещинам напластования, условно относящимся к палеогену. На закарстованном палеорельефе сформированы аллювиально-склоновые, пролювиальные и аллювиальные отложения палеоген-неогена, в том числе алмазоносные за счет промежуточных коллекторов алмазов (прибрежно-морских и дельтовых отложений ордовика, нижнего силура и нижнего девона). В четвертичную эпоху при глобальном похолодании депрессии закрываются ледниковыми, водно-ледниковыми, делювиально-солифлюкционными, флювиогляциальными, озерно-ледниковыми, озерными и делювиальными отложениями. По зандровым долинам образовались флювиогляциальные отложения значительной мощности, по склонам и трогам - курумы и каменные реки. Формируется современный рельеф и гидросеть с комплексом террас. На некоторых депрессиях образованы верховые болота с озерами. Стратиграфами и геологами на западном склоне Урала традиционно палеогеновыми считаются только олигоценовые аллювиальные отложения $\left(a \mathrm{P}_{3}\right)$, к которым отнесены белоцветные или желтовато-белые галечники и пески с примесью каолинит-гидрослюдистых глин мощностью 3-5 м. 


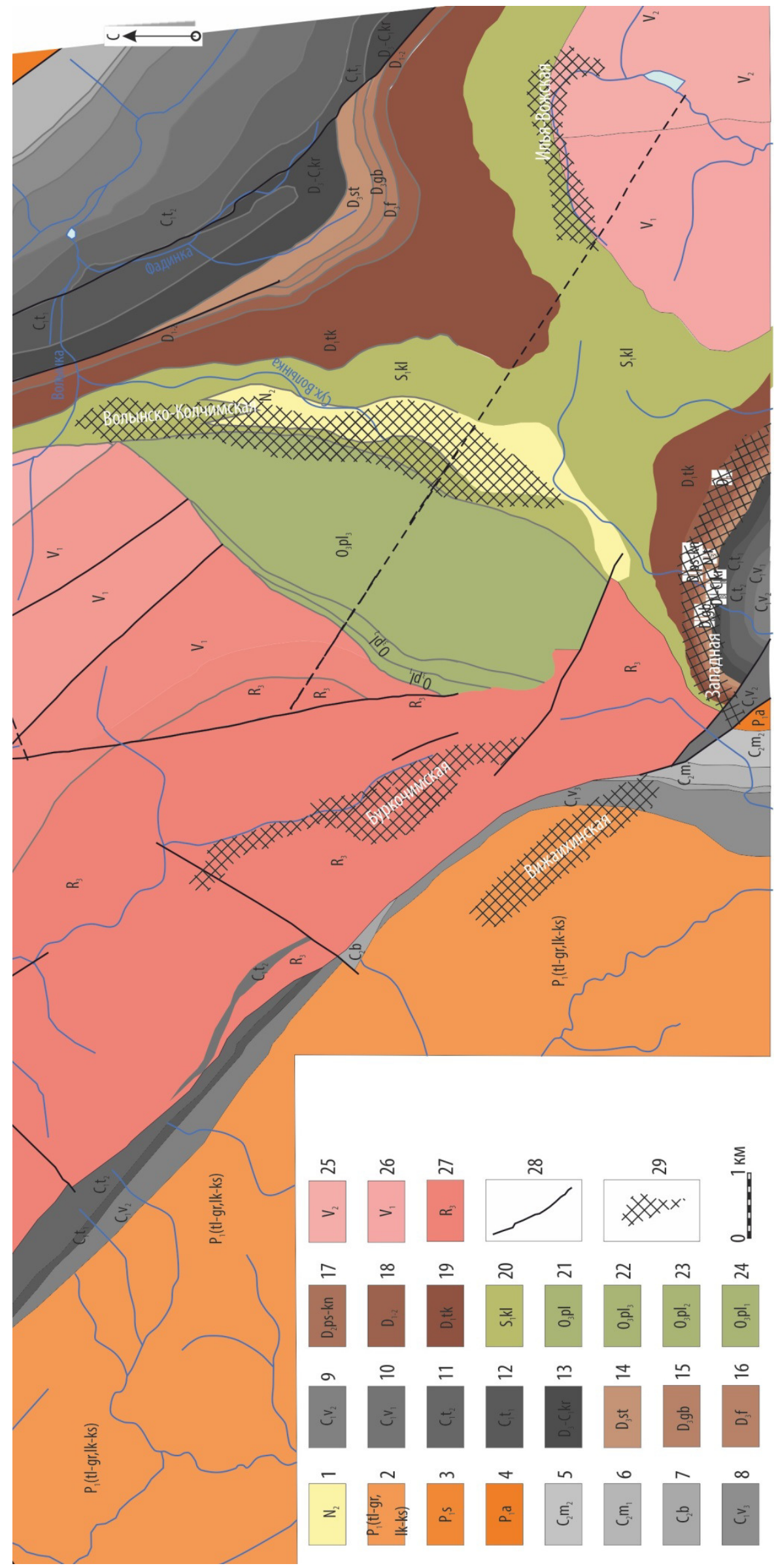

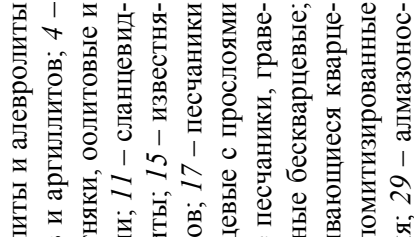

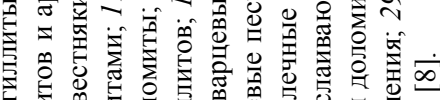

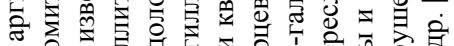

$\sim$

矛

충

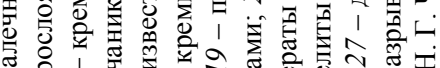

运啳

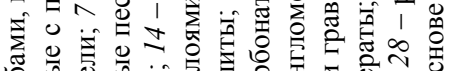

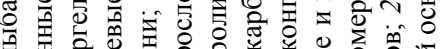

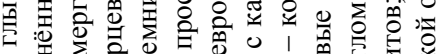

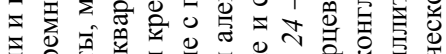

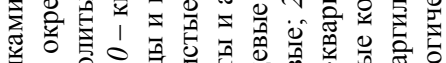

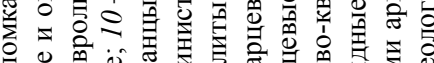

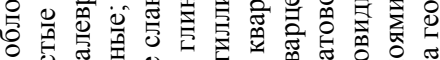

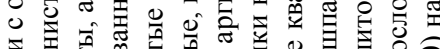

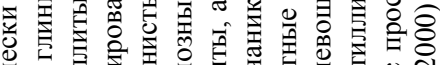

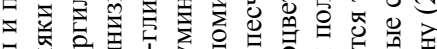

真要

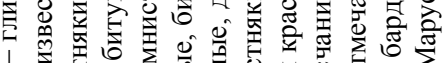

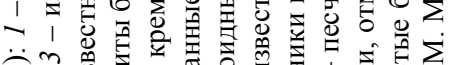

$\widehat{\bar{A}} m$ 鱼

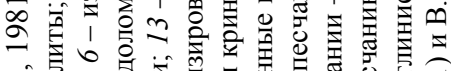

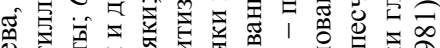

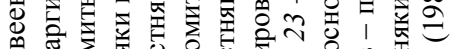

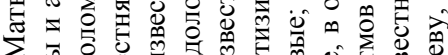

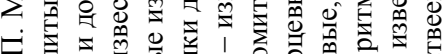

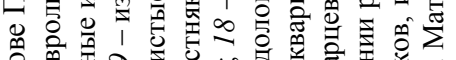

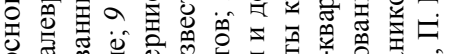

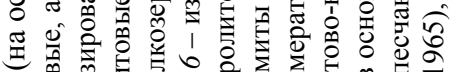

웅

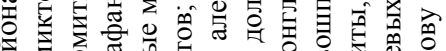

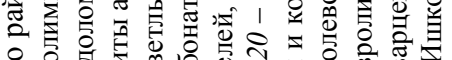

응

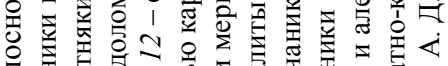

평 픈

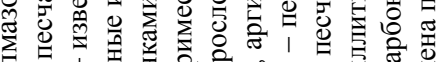

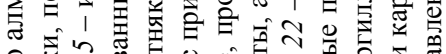

일 $n$

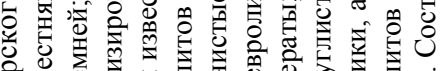

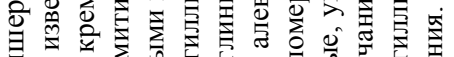

ตํ.

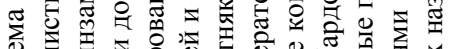

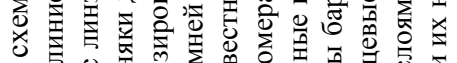

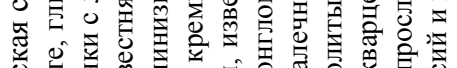

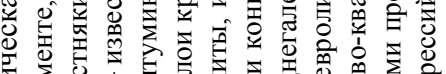

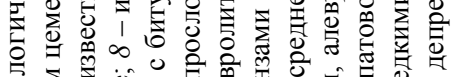

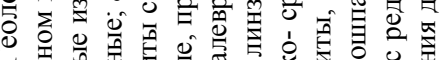

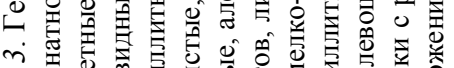
仓。을

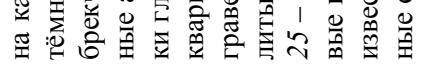


Крупные купольные поднятия, связанные с усиливающимся давлением со стороны уральских структур на перикратонное окончание ВосточноЕвропейской платформы, образованы в неоген-четвертичный период в пределах Полюдовско-Колчимского антиклинория, где впервые С. Н. Петуховым, В. В. Куртлацковым и др. (2000 г.) выделен ряд сдвиговых структур растяжения северо-восточного простирания с шагом заложения от 10 до 14 км.

Морфология и литология алмазоносных депрессий

Сформированные депрессии в карбонатных породах являются звеньями почти непрерывной цепи, опоясывающей приядерную часть Колчимской антиклинали и косвенно приуроченной к контакту пород силура $\left(\mathrm{S}_{1} \mathrm{kl}\right)$ и терригенных пород вендкембрия [10]. В разрезе депрессий развиты мезозойкайнозойские отложения [11].

В подошве - олигоценовые коры выветривания, структурный и бесструктурный мезозойский элювий и спорадически сохранившиеся терригенные белоцветные отложения. На них залегают переотложенные в миоцене красноцветные терригенные отложения с алмазами. Мезозойские породы перекрываются четвертичными образованиями делювиально-пролювиального, водно-ледникового, ледникового, озерноледникового и делювиально-солифлюкционного генезиса. Голоценовые делювиальные, спорадически болотные отложения и почвенно-растительный слой сплошным чехлом, кроме коренных выходов, перекрывают нижележащие образования [12].

\section{Волынско-Колчимская депрессия}

Депрессия впервые вскрыта Васильевым и др. (1961 г.), им же обнаружены алмазы, обоснована как депрессия В.А. Ветчаниновым, Г.Д. Мусихиным и др. (1968 г.), и затем закартирована И.С. Ситдиковым и др. (1994 г.) в пределах бассейна среднего течения р. Вишеры и приурочена к левому борту долины её левого притока p. Большого Щугора. Развита по контакту колчимских карбонатных пород $\left(\mathrm{S}_{1} \mathrm{kl}\right)$ и терригенных пород вендкембрия (как Рассольнинская и Илья-Вожская) (рис. 4a). В результате деятельности водотоков по тектонически ослабленным трещиноватым зонам произошли выщелачивание и эрозия карстующихся пород. В плане они сформировали вытянутую отрицательную форму длиной более 7600 м, а в поперечном сечении корытообразный профиль шириной не более 900 м с элементами V-образных врезов, поперечник которых достигает 125 м. Заполняющие её породы имеют полифациальный генезис [13], слагая девять слоёв, отражающих основные условия осадконакопления.

Нижний девятый слой подстилается глинами чёрно-серо-бурыми с щебнем и валунами колчимских доломитов и доломитизированных известняков мощностью 0,4-9,0 м, которые фрагментарно покрыты венд-кембрийскими желтовато-зелёными аргиллитами с прослоями алевролитов мощностью 0,2 м в виде дресвы и щебня. Рыхлые отложения представлены светло-серым разнозернистым песчаником с примесью гравия. Встречаются линзы вишнево-красных гематитизированных гравелитов, мелко-галечные конгломераты на глинистом цементе (размер галек до 3 см). Мощная толща глинисто-щебнисто-глыбового материала сконцентрирована у подножия крутой части склона увала. Основную массу представляют продукты разрушения песчаников и конгломератов полюдовской свиты, развитых на западном борту депрессии. Наличие в её отложениях существенной примеси каолинита и монтмориллонита указывает на участие в формировании продуктов размыва кор выветривания донеогенового возраста. В восточном борту переотложены песчаники такатинской свиты.

Выше в восьмом слое $\left(a \mathrm{~N}_{2}\right)$ залегает красноватокоричневый и жёлто-бурый сильно ожелезнённый гравий мощностью 2,6-6,6 м с щебнем и галькой на слабом глинистом цементе. Обломки такатинских пород и гипотетические минералы-спутники алмазов отсутствуют.

Седьмой слой $\left(a \mathrm{~N}_{2}\right)$ мощностью $\sim 5,4$ м характеризуется переотложенными зрелыми аллювиальными породами. Его основание сложено красноватокоричневым и жёлто-бурым сильно ожелезнённым гравием с щебнем и галькой на слабом глинистом цементе. Наряду с преобладанием гальки II-IV класса окатанности присутствует большое количество неокатанных. Литология всего слоя схожа с таковой пород такатинской, колчимской и полюдовской свит. Преобладают кварцевые и полевошпатово-кварцевые разнозернистые песчаники серого, светло-серого, сиреневого и розового цветов на иллитовом цементе. Кварцевые галька и гравий заимствованы на $15 \%$ из такатинских отложений и на $85 \%$ из полюдовских конгломератов.

Выше делювиально-пролювиальные глины и песчаники общей мощностью до 14 м слагают шестой слой $\left(d p \mathrm{~N}_{2}\right)$. В нём плотная, сильно ожелезнённая песчанистая глина красновато-коричневая и охристобурая содержит редкие несовершенно окатанные валуны, щебень и гальку. Обломочная часть представлена светло-сиреневыми и сиреневыми мелкосреднезернистыми песчаниками, а также серыми конгломератами и белыми, розовато-белыми галькой и гравием кварца. Обломочная часть совпадает с полюдовскими гравелитами и конгломератами западного борта депрессии. При этом большинство галек и валунов покрыты буроватой плёнкой.

Иллитовые глины пятого слоя (ld $\left.\mathrm{Q}_{\mathrm{II}}\right)$ мощностью 5,7 м с незначительной примесью песка голубоватосерого до зеленовато-серого и бурого цветов слабо ожелезнены и содержат до 40\% валунно-щебнистодресвяного материала. Крупность валунов меньше, чем в перекрывающем слое, а их окатанность достигает II класса. Обломочная часть представлена кварцевыми светло-серыми, сиреневыми, светлосиреневыми, мелко- и среднезернистыми песчаниками, а также серыми конгломератами и белыми, розовато-белыми галькой и гравием кварца. Последние по облику и составу схожи с полюдовскими гравелитами 

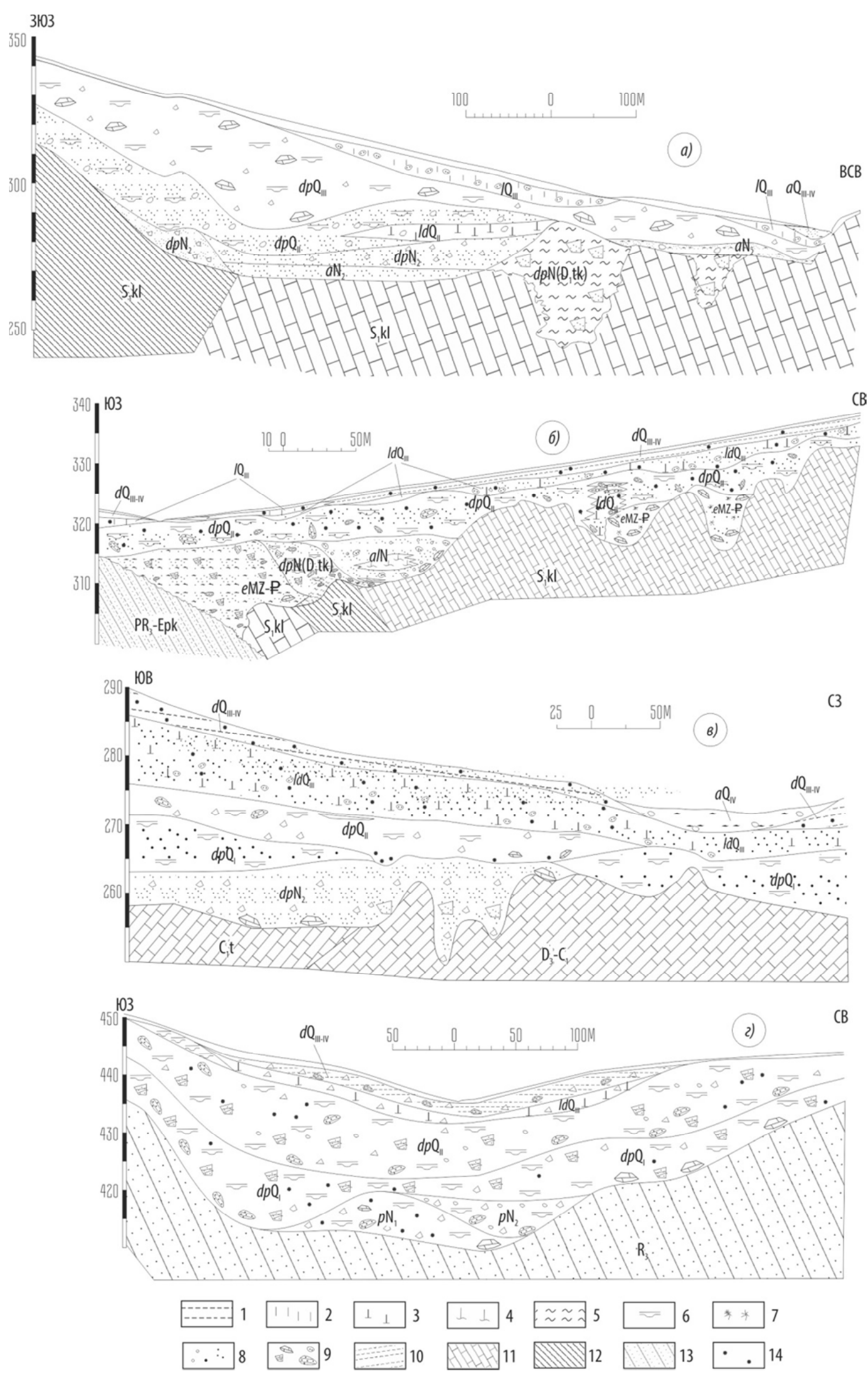

Puc. 4. Геологические разрезы кайнозойских депрессий: $a$ - Волынско-Колчимская, пр. 124; 6 - Илья-Вожская, профиль 214; в - Западная, профиль 11 ; г - Буркочимская, профиль Б16. 1 - глины охристые, 2 - глины торфовидные, 3 - глины слоистоохристые, 4 - озёрно-аллювиальные глины, 5 - аллювиальные глины, 6 - делювиально-пролювиальные глины, 7 - карбонатная мука, 8 галька, гравий, песок, 9 - глыбы, валуны, щебни, 10 - алевролиты, 11 - карбонатные породы, 12 - аргиллиты, 13 - песчаники, 14 марганцевые и железистые гидроксиды и бобовины лимонита. 
и конгломератами западного борта депрессии.

Красновато-бурые до охристо-бурых иллитовые глины четвёртого слоя $\left(d p \mathrm{Q}_{\mathrm{II}}\right)$ мощностью $4,4-19,0$ м в значительном количестве содержат глыбы и валуны полюдовских конгломератов с линзами песка и реже гравия. Эти пролювиально-делювиальные образования обычно слагают наиболее мощную толщу рыхлых отложений депрессии и залегают по стратиграфическим признакам ниже горизонта верхнеплейстоценовых делювиальных и озёрно-делювиальных глин.

Светло-коричневые иллитовые глины третьего слоя $\left(l \mathrm{Q}_{\mathrm{III}}, l d \mathrm{Q}_{\mathrm{III}}\right)$ мощностью $3,3-9,9$ м с линзами и гнёздами серой, зеленовато-серой глины содержат примесь делювиальных грубообломочных пород. Слой считается потенциально-алмазоносным из-за единичных зёрен алмазов.

Бурые глины второго неалмазоносного слоя $\left(d \mathrm{Q}_{\text {III }}\right)$ мощностью 1,7-3,8 м залегают под покровными суглинками и распространены повсеместно. В основании слоя сплошной настил глыб, валунов и обломков полюдовских песчаников.

Покровные суглинки первого неалмазоносного слоя $\left(d \mathrm{Q}_{\mathrm{IV}}\right)$ мощностью $0,2-0,8$ м распространены повсеместно. Отмечаются глыбы полюдовских песчаников и конгломератов размерами до $1,0 \times 1,2 \times 1,8$ м, в логах и ручьях их количество до $20 \%$.

В северной части депрессии отложения убого алмазоносны. Это объясняется разубоживанием кайнозойских отложений материалом полюдовской свиты и не содержащей алмазов такатинской свитами, с которых поступал материал, а также отсутствуем влияния промежуточного коллектора базальной толщи колчимской свиты.

\section{Илья-Вожская депрессия}

Ветчаниновым В. А., Коневым П. Н. и Срывовым А. П. и др. (1967 г.) депрессия выделена в результате геолого-поисковых работ с крупнообъемным опробованием на Ишковском, Илья-Вожском, БольшеКолчимском и Западном участках, Мусихиным Г. Д. и др. (1969 г.) описаны её отложения и доразведана Матвеевым П.М., Марусиным В.М., Лученко Г.С. и др. (1983) совместно с россыпью алмазов р. Кривой. Депрессия в виде изогнутой линейной коррозионноэрозионной формы с развитием в ней переотложенных и закарстованных пород длиной до 7000 м и шириной 200-700 м. Она развита в зоне контакта колчимских карбонатных пород с терригенными породами чурочной и полуденно-колчимской $\left(\mathrm{PR}_{3}-\epsilon_{\mathrm{pk}}\right)$ свит на северо-западном замыкании Тулым-Парминской антиклинали (рис. 4б). Глубина депрессии колеблется от 5 м до 10 м на бортах и до 40 м в осевой части. По геофизическим данным Мельникова И. Ф. и Демченко В .С. (1969 г.) в южной части Илья-Вожской депрессии рыхлые отложения представлены отдельными линейно вытянутыми участками шириной 200-300 м (до 1000 м) и мощностью $20-40$ м, реже 60 м. В восточной части депрессии проявлен край Фадинской депрессии, развитой в отложениях верхнего девона- карбона. Западная часть Илья-Вожской депрессии шириной до 1500 м, при мощности рыхлых отложений до 40 м, хорошо выражена на всём протяжении. Восточная часть шириной 300-400 м состоит из ряда депрессионных зон [13], вытянутых линейно, с крутым V-образным профилем.

Северная часть депрессии длиной 3 км имеет, как и р. Кривая, субширотное простирание (профили 190212 ) и юго-восточное (профили 212-264). В западной части (профиль 190) депрессия делится на две ветви, на которых южная замыкается в 300 м от местонахождения профиля 190 , а северная в виде рукава имеет ширину 200-250 м. В депрессии южнее профиля 264 проявлен пережим (профили 231 и 272), а затем она вновь расширяется до 700 м (пр. 268), протягиваясь в отличие от направления р. Кривая на юго-восток на 4 км, с охватом уже территории верхнего течения p. Илья-Вож. В зоне разлома, сопряженного с БольшеКолчимским разломом, ниже по р. Илья-Вож (выше устья р. Быстрой) В. Я. Колобяниным, В. С. Демченко, А. М. Чумаковым и др. (1993 г.) наблюдены дробление пород, их мощная хлоритизация, окварцевание и баритизация, а также резкое возрастание алмазоносности.

Отложения депрессии имеют полифациальный генезис, разделяются на пять алмазоносных $\left(a \mathrm{Q}_{\mathrm{III}}, l d \mathrm{Q}_{\mathrm{II}}\right.$, $\left.d-p \mathrm{Q}_{\mathrm{II}}, d-p \mathrm{~N}, e \mathrm{MZ}-\mathrm{P}\right)$ и верхний неалмазоносный $\left(d \mathrm{Q}_{\mathrm{IV}}\right)$ слои. Алмазоносные отложения Илья-Вожской депрессии сложены преимущественно делювиальнопролювиальными глинами неогена (мощностью 5,012,4 м) и среднеплейстоценовыми глинами $(2,0-15,0$ м), которые имеют различное количество обломочного материала, сложенного преимущественно песчаниками такатинской свиты с примесью гальки и гравия кварца. Они переходят на отдельных участках в болотно-делювиальные или озёрно-болотные отложения мощностью 1,4-4,2 м, включающие линзовидные тела аллювиальных, аллювиально-делювиальных и аллювиально-болотных отложений различного возраста, с незначительным количеством гравия кварца, иногда щебня такатинских песчаников. Почти повсеместно перекрыты делювиальными и болотными глинами и суглинками верхнего плейстоцена и голоцена. Подстилающими являются мезозойско-кайнозойские элювиально-делювиальные и элювиальные образования, представленные либо тёмно-коричневыми глинами с включением доломитовой муки и обломков карбонатных пород, либо светло- и желтовато-серыми кварцевыми песками с обломками кварцевых песчаников и карбонатных пород. Мощность этих отложений колеблется в широком диапазоне от долей до десятков метров, достигая на V-образных участках 30 40 м (профили 206, 198, 194). Для формирования россыпей этого типа предполагается благоприятной мелпалеоцен-эоценовая эпоха образования площадных кор выветривания [14].

Гранулометрический состав рыхлых отложений (рис. 5), выполняющих Илья-Вожскую депрессию, характеризуется высоким содержанием песчано- 


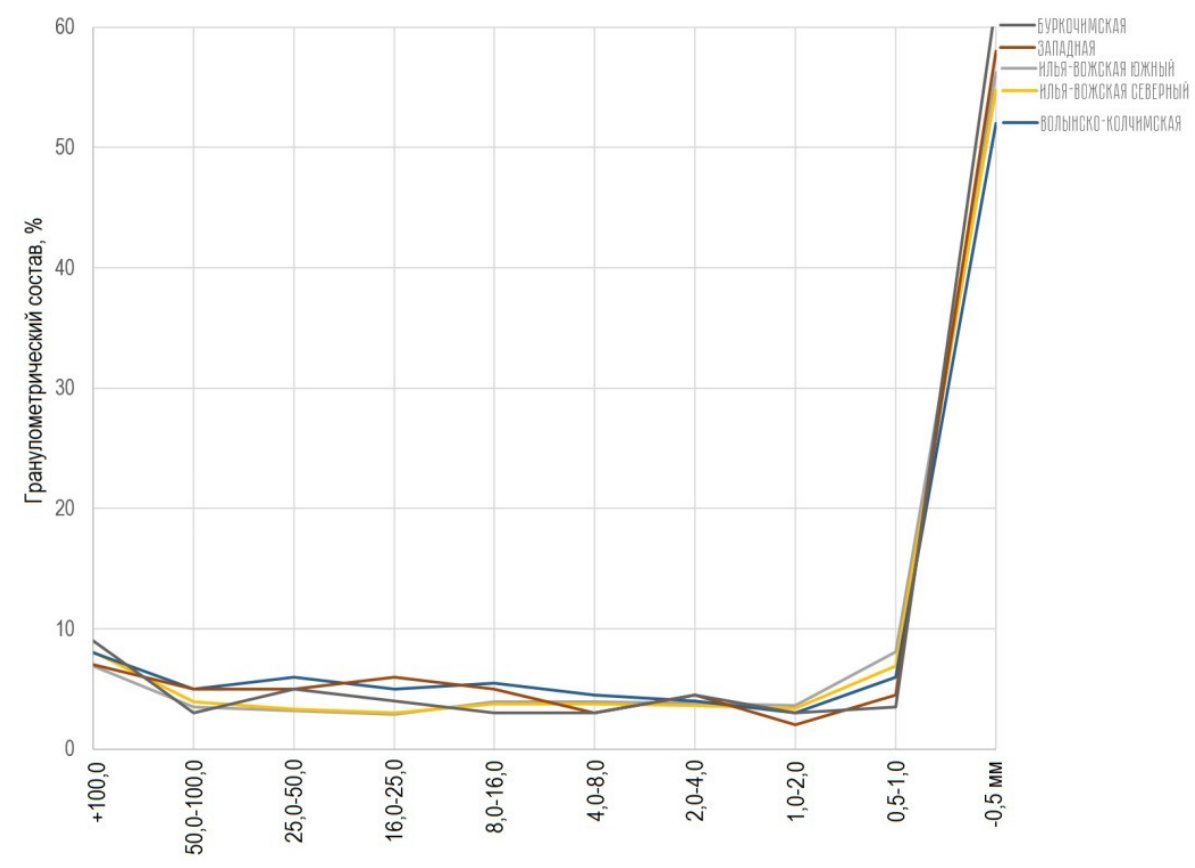

Puc. 5. Гранулометрический состав рыхлых отложений кайнозойских алмазоносных депрессий Вишерского района.

глинистого материала $(<0,5$ мм), превышающим в большинстве случаев 50-60\%. Наибольшее содержание этого материала (67\%) констатировано в аллювиальных верхнеплейстоценовых и элювиальноделювиальных мезозойско-палеогеновых отложениях. В аллювиально-болотных и озерно-болотных отложениях оно составляет не более $42 \%$ и лишь в аллювиальных голоценовых и аллювиально-делювиальных среднеплейстоценовых образованиях снижается до $20 \%$. На отдельных участках, особенно на поверхности, отмечается значительное количество валунов класса +300 мм.

\section{Западная депрессия}

Оконтурена Ю. Г. Германом и В. П. Беляевым (1972 г.) в субширотном направлении на 5500 м при ширине 650-1400 м вдоль южного склона увала (монаднока) такатинских песчаников. Приурочена к карбонатным породам $\left(\mathrm{D}_{3}-\mathrm{C}_{1}\right)$ юго-западного крыла Тулым-Парминской антиклинали и расположена на левобережье верхнего течения р. Сев. Колчим между её меридиональным отрезком и ключом Светлый, которые трассируют тектонические нарушения. Депрессия представляет собой карстово-эрозионную долину, выполненную аллювиальными, пролювиально-делювиальными, озёрно-пролювиальными и делювиальными отложениями (MZ-KZ) мощностью 10-42 м (Соколов О. В., Шимановский В. А., 1973 г.).

Северной границей депрессии является подножие монаднока, образованного такатинскими песчаниками. Ложе депрессии имеет корытообразную, с уплощенным днищем, форму и сложено карбонатными породами в диапазоне от $\mathrm{D}_{1-2}$ до $\mathrm{C}_{1}$ (рис. 4в). Ампли- туда между бортами и межслоевыми шовными зонами, наиболее глубокими участками ложа депрессии, превышает 40 м. Выположенные участки бортов чередуются с почти отвесными (перепад высот 10 м и более). Разрез рыхлых отложений Западной депрессии имеет четко выраженное слоистое строение, совпадающее в целом со строением Волынско-Колчимской депрессии.

С поверхности до глубины 10,0-15,0 м залегают делювиальные отложения

плейстоцен-голоценового возраста $\left(d \mathrm{Q}_{\text {III-IV }}\right)$, а также озерные, озерно-делювиальные, делювиально-пролювиальные, гляциально-аллювиальные и ледниковые отложения среднего плейстоцена $\left(l, l d, d p, f, g, g a \mathrm{Q}_{\mathrm{II}-\mathrm{III}}\right) \mathrm{c}$ такатинским крупнообломочным материалом. Ниже них и до плотика залегают плиоценовые пески, разделенные в разрезе на два слоя: верхний «красноцветный» $\left(d p \mathrm{~N}_{2}-\mathrm{Q}_{\mathrm{I}}\right)$ и нижний - «желтоцветный» $\left(p, a \mathrm{~N}_{2}\right)$.

\section{Буркочимская депрессия}

Депрессия выделена В. И. Повонским, В. Я. Колобяниным, Ю. И. Погореловым и др. (1977 г., 1979 г.) как западное ответвление на юге ВолынскоКолчимской депрессии в составе Больше-Колчимской депрессии, в верховьях р. Большой Колчим, примыкая с юга и юго-востока к хребту Помяненный камень (северный борт депрессии), образуя небольшой предгорный прогиб длиной около 5650 м и шириной до 1100 м. Затем она В. М. Марусиным (1981-1990 гг.) обоснована как самостоятельный геологический объект, являясь фронтальной частью Колчимского надвига северо-западной экспозиции, с оперяющими его разломами, где обнаруживается точка тройного сочленения древних (рифейских) и палеозойских (ордовик и силур) пород, с юга ограничиваясь такатинским увалом.

По плотику депрессия разделяется на северную и южную части. В центральной части депрессии залегают карбонатные породы палеозоя; северный и северо-восточный борт - карбонатные породы низьвенской $\left(\mathrm{PR}_{3} \mathrm{nz}\right)$ и деминской $\left(\mathrm{PR}_{3} \mathrm{dm}\right)$ свит верхнего рифея; южный борт - дезинтегрированные породы такатинской свиты (рис. 4г).

Выше по разрезу залегают нижнеплейстоценплиоценовые алмазоносные отложения, по вещественному составу отвечающие переотложенным 
такатинским (восточный борт депрессии, скв. 49-44) и колчимским (западный борт депрессии, скв. 50-57) базальным толщам. Алмазоносные отложения разделены на два слоя: верхний - «красноцветный» $\left(d p \mathrm{~N}_{2}-\mathrm{Q}_{\mathrm{I}}\right)$ и нижний - «желтоцветный» $\left(p, a \mathrm{~N}_{2}\right)$.

Они перекрываются делювиальными отложениями верхнего плейстоцен-голоцена ( $\left.d \mathrm{Q}_{\mathrm{III}-\mathrm{IV}}\right)$, а также озерными, озерно-делювиальными, делювиальнопролювиальными, флювиогляциальными, ледниковыми и гляциально-аллювиальными отложениями верхнего и среднего плейстоцена $\left(l, l d, d p, f, g, g a \mathrm{Q}_{\mathrm{II}}\right.$ III) с полюдовским крупнообломочным материалом.

\section{Минеральный состав отложений депрессий}

Минеральный состав шлихов довольно однообразен и в основных чертах схож для отложений в рассмотренных депрессиях (рис. 6). Основную массу шлиха составляют: лимонит, гематит, сидерит, циркон, рутил, лейкоксен и гранаты. В единичных зернах встречаются барит, сфен, корунд, ильменит, ксенотим, монацит и и др.

Состав тяжёлой фракции неогеновых слоёв аналогичен таковому такатинских и колчимских песчаников. В ней резко преобладает циркон, в меньшей степени турмалин, рутил, лейкоксен. Значительная доля принадлежит аутигенным минералам - лимониту, гематиту, пириту. В самой большой (ВолынскоКолчимской) депрессии в 3 слое присутствуют гранаты $(0,2 \%)$ и в единичных зёрнах (далее е.3.) хромит и моноцит; под суглинками Илья-Вожской депрессии - переотложенные такатинские песчаники с алмазами. В 4 слое Волынско-Колчимской в е.з. моноцит, сфалерит, гранаты, эпидот, цоизит, местами смектиты. В 6 слое также в е.з. моноцит, сфалерит, гранаты, эпидот и цоизит. В подстилающем слое (седьмом) в е.з. барит, пироп, пикроильменит с псевдоморфозами лейкоксена, хромшпинелид. Восьмой слой схож с седьмым слоем, но отличительной особенностью является отсутствие в обломках такатинских пород и МСА, алмазы не обнаружены. В приплотиковом слое преобладают лимонит, циркон и турмалин, а также встречаются лейкоксен, анатаз, рутил, хромит, алмазы. Восточный борт ВолынскоКолчимской депрессии (уч. Сухая Волынка) насыщен пиропами и хромшпинелидами. Зёрна пиропов размером преимущественно до 1 мм, а более 1 мм составляют 3-9\%. Они фиолетово-красные (60\%), красные $(17 \%)$, оранжево-красные $(10 \%)$, розовые (7\%), бледно-сиреневые (4\%), е.з. - малиновые. Хромшпинелиды в виде овализированных и округлых октаэдров имеют размеры 0,2-0,5 мм, изредка до 1,6 мм.

Общая минералогическая ассоциация отложений в Буркочимской и Западной депрессиях - лейкоксентурмалин-фосфатная с монацитом и хромшпинелидом. В районе линии 178 Буркочимской депрессии шурфами 2393 и 1901 вскрыты зеленовато-синие озёрно-болотные отложения, состоящие из хлорита $(60 \%)$ и монтмориллонита $(40 \%)$, заполняющими поры с алмазами. Последние содержатся в струе, тянущейся вниз по восточному склону хребта Дресвяная Степь.

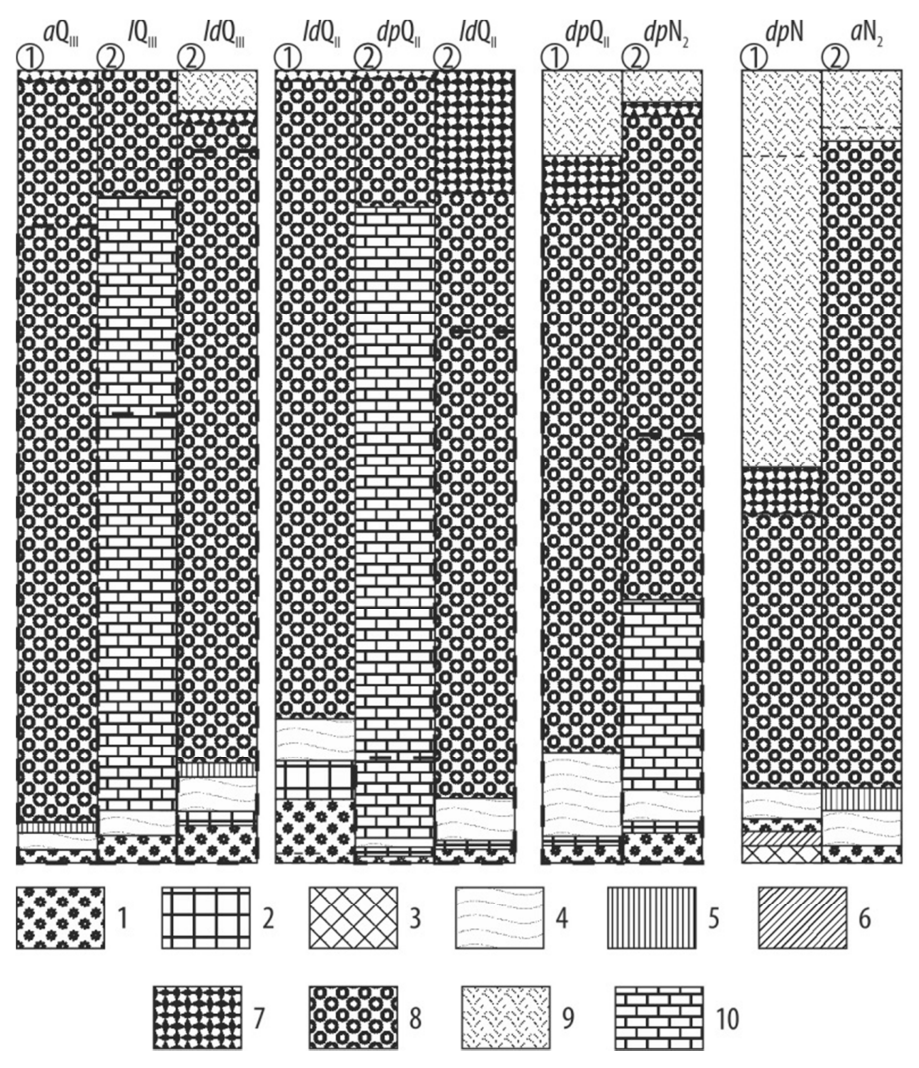

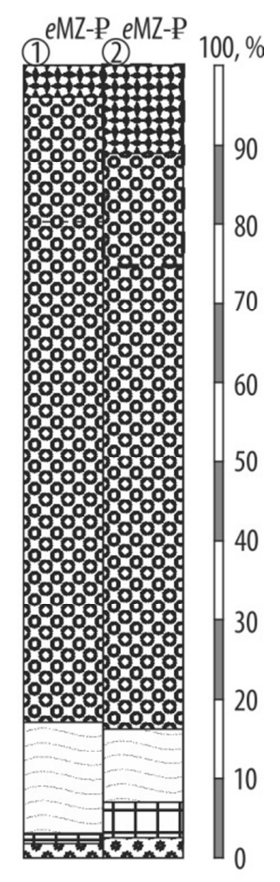

เニ-」 Лимонит
Рис. 6. Минеральный состав отложений Илья-Вожской (1) и Волынско-Колчимской (2) депрессий: 1 - рутил, 2 - анатаз, 3 магнетит, 4 - лейкоксен, 5 - хромит, 6 - титаномагнетит, 7 - турмалин, 8 - циркон, 9 - г/о магнитные, 10 - сидерит. Пунктиром показано содержание лимонита в процентах от веса тяжёлой фракции шлиха. Содержание других минералов на диаграмме рассчитано без учёта лимонита. Нижний слой справа, самый верхний слева. 
Таким образом, минеральный состав отложений рассмотренных депрессий в целом схож. Вариации содержаний тех или иных минералов зависит от интенсивности эрозии докайнозойских пород. Наличие алмазов в отдельных слоях депрессий контролируется дальностью переноса размытых такатинских или колчимских базальников, последние являются и их индикаторами. Причиной сохранения неустойчивых минералов в рыхлых четвертичных образованиях явилось высвобождение этих минералов из обломков в условиях преимущественно физического выветривания, недалекого переноса, а также дробления при аллювиальной переработке материала.

\section{Выводы}

Таким образом, в допалеогеновое время при растворении карбонатных пород и выноса растворённых продуктов коррозионно-эрозионные формы, частично выполненные алмазоносными отложениями девонских и силурийских промежуточных коллекторов. При их размыве в заложенных депрессиях образовались алмазоносные россыпи кайнозоя.

Характерной особенностью депрессий является закономерное литолого-генетическое и стратиграфическое строение их разрезов. Внизу, на палеозойском плотике такатинской $\left(\mathrm{D}_{1} \mathrm{tk}\right)$, эфельской $\left(\mathrm{D}_{1} \mathrm{ef}\right)$ и полюдовской $\left(\mathrm{O}_{3} \mathrm{pl}\right)$ свит и развитых по нему мезозойских корах выветривания, залегают неогеновые аллювиально-делювиальные, аллювиально-пролювиальные и пролювиальные отложения, содержащие промышленные концентрации алмазов. Гранулометрия отложений депрессий сопоставима и хорошо коррелируется, что указывает на схожие условия осаждения материала. Данные минералогического анализа говорят о большой роли в россыпеобразовании предтакатинских и мезокайнозойских химических кор выветривания.

Алмазоносные породы депрессий, хотя и поддаются стратификации, но по существу являются промежуточными образованиями между корами выветривания и продуктами их переотложения в кайнозое. В этом кроется ответ на большое литологическое сходство осадочных толщ различных по возрасту депрессий.

Обогащение алмазами четвертичных русловых россыпей происходило за счёт размыва россыпей палеоген-неогеновых депрессий и в меньшей степени за счёт размыва докайнозойских промежуточных коллекторов.

Анализ взаимоотношений коррозионно-эрозионных депрессий и речных долин позволит дать прогнозную оценку ресурсов алмазов россыпей и направление поисковых работ.

ООО «Норильскгеология», г. Санкт-Петербург

Никулин Иван Иванович, доктор геолого-минералогических наук, заместитель директора по развитию геологоразведочных работ

E-mail: iinikulin@gmail.com; Тел.: +7 (3919) 313942

\section{ЛИТЕРАТУРА}

1. Чочиа, Н. Г. Геологическое строение Колво-Вишерского края / Н. Г. Чочиа. - Л.: Гостоптехиздат, 1955. - 407 с.

2. Степанов, И. С. Новый тип месторождения алмазов на Урале / И .С. Степанов // Докл. АН СССР. - 1967. - Т. 177. № 5. - С. 1166-1169.

3. Степанов, И. С. Карстовые промежуточные коллекторы алмазов на Урале / И. С. Степанов // Известия ВУЗов. Геология и разведка. - 1985. - № 3. - С. 32-38.

4. Сигов, B. A. Основные этапы геоморфологического развития Вишерского алмазоносного района / В. А. Сигов, Л. Е. Стороженко // В сб. Совещание по геологии алмазных месторождений (тезисы докладов). - Пермь, 1966. - С. 101104.

5. Козубовский, А. И. Вишерские алмазы на Урале / А. И. Козубовский, А. Д. Ишков, В. Б. Белов // Разведка и охрана недр. - 1967. - № 7. - С. 78-91.

6. Степанов, И. С. Особенности строения россыпей в пределах эрозионно-карстовых депрессий западного склона Урала / И. С. Степанов, Г. Н. Сычкин // В сб. Аллювий. Межвузовский сборник научных трудов. - Пермь, ПГУ, 1983. - C. 44-46.

7. Степанов, И. С. Некоторые типы россыпей алмазов карстовых депрессий западного склона Урала / И. С. Степанов, Г. Н. Сычкин // В сб. Гидрогеология и карстоведение. - Пермь, 1975. - Вып. 7. - С. 27-32.

8. Геологическая карта Урала. Масштаб 1:200000. - Р-40XXXIV. -1966.

9. Казымов, К. П. К методике изучения кайнозойских образований эрозионно-структурных депрессий Урала в связи с их алмазоносностью / К. П. Казымов // В сб. Аллювий Западного Урала - источник многих полезных ископаемых. Тезисы докладов участников научнотехнического семинара 17 ноября 1988 г. - Пермь, ПГУ, 1988. - C. 33-37.

10. Казымов, К. П. Условия образования и вещественный состав кайнозойских отложений эрозионно-карстовых депрессий западного склона Среднего и Северного Урала в связи с их алмазоносностью / К. П. Казымов // Автореферат дисс. на соиск. уч. ст. канд. геол.-минер. наук. - Пермь, ПГУ, 1992. - $18 \mathrm{c}$.

11. Кораблев, А. Г. Особенности геологического строения месторождений алмазов Северного Урала и проявлений потенциально алмазоносных работ Южного Урала / А. Г. Кораблев // Дисс. на соиск. уч. ст. канд. геол.-минер. наук. Миасс, 2002. - 168 с.

12. Россыпи алмазов мира / В. М. Подчасов [и др.]. - М., ООО «Геоинформмарк», 2005. - $747 \mathrm{c.}$

13. Наумова, О. Б. Атлас форм рельефа / О. Б. Наумова // Том третий. Формы рельефа Прикамья. - Пермь, ПГУ, 2001. $-316 \mathrm{c}$.

14. Государственная геологическая карта Российской Федерации. Масштаб 1:1 000000 (новая серия) Лист Р-40,

41 - Североуральск / Отв. ред. О.А. Кондиайн //

Объяснительная записка. - СПб., ВСЕГЕИ, 1995.

\section{Norilskgeogy, St. Petersburg}

Nikulin Iv.Iv., Doctor of Geological and Mineralogical Sciences, Deputy Director for Geological Exploration

E-mail: iinikulin@gmail.com

Tel.: +7 (3919) 313942 